nerves without the necessity of consulting a text-book of anatomy, and consequently the introduction of such a chapter as that with which we are now dealing gives additional value to the treatise. We are of the opinion, however, that the association of a clinician with the anatomist would have increased the value of this section.

Parts III, IV, and V deal in great detail with the anatomy of the nasal and accessory nasal cavities; it seems only natural to expect them to be written by Professor Onodi, of Budapest, than whom no one is more competent to do so. To those already acquaintel with Onodi's work what is here written and illustrated will be familiar, as it is mainly at reproduction of his already well-known atlas; consequently a review in detail at this date hardly seems called for. The illustrations form a striking feature of the text-book, and if the same standard is to be maintained in the elinical volumes as in the anatomical introduction they will greatly add to the value of the publication, and we look forward with interest to their appearance. A. Logan Turner.

\title{
NEW INSTRUMENT.
}

\section{A Simple Nasal Speculum.}

By James Doneran.

Surgeon to the Throat Department, Italian Hospital, London.

The nasal speculum shown in the adjoining ent was copied from ont made from a hair-pin in an emergency.

The wire is bent in such a way that the loops forming the blates

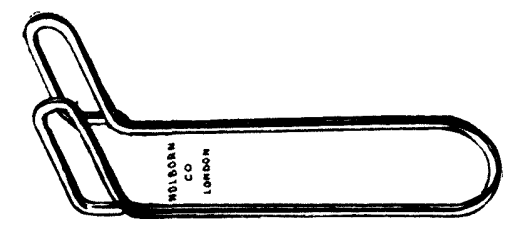

support themselves without soldering. The speculum is efficient, sterilisable, and costs only sixpence. It is made by the Holborn Surgical Instrument Company, and will be found useful in out-patient work or wherever a ready succession of fresh instruments is required.

\section{BOOKS RECEIYED.}

Diseases of the Nose and Throat, Comprising Affections of the Trachea and Esophagus. A Text-book for Students and Practitioners. By StClair Thomson, M.D., F.R.C.P.Lond., F.R.C.S.Eng. With is plates and 294 figures in the text. London, New York, Toronto, and Melbourne: Cassell \& Co., Ltd., 1911.

Der Schwindel (Vertigo). By Dr. E. Hitzig. Zweite Auflage von .J. Rich, Ewald, und Robert Wollenberg, Strassburg. Mit 12 Abbildungen. Wien und Teipzig: Alfred Hölder, 1911.

Handbuch der Speciellen Chirurgie des Ohres und der oberen Luftwege. Herausgegeben von Dr. L. Katz, Dr. H. Preysing, und Dr. $F$. Blumenfeld. Bd. i, Hälfte 1, Lief 6 , und Bd. i, Hälfte 2 , Lief 1. 


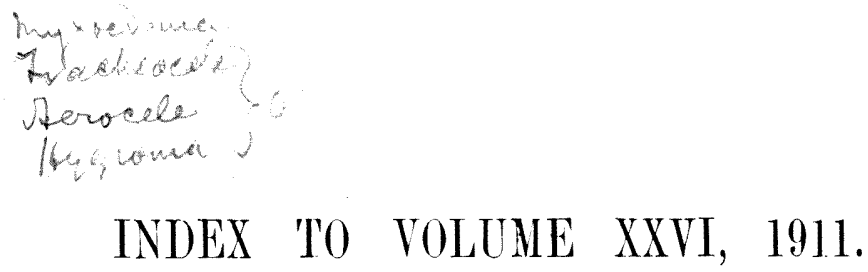

\section{SUBJECTS.}

Abductor paralysis, see Cords, vocal.

Acoustic nerve, see Auditory nerve.

Adductor paralysis, see Cords, vocal.

Adenoids (J. Symington) anæsthesia for removal of (F. Guyot, Lautmann, Rupprecht)

\section{and the hypophysis (Citelli)}

American Laryngological, Rhinological, and Otological Society

President's Address (Logan) .

$101,151,271,317,653$

\section{Rhinological and Otological Society}

Anæsthesia, nasal reflex during (J. Blumfeld)

Antrostomy, nasal, burr for (S. Hastings).

Antrum, maxillary, anatomy of (J. P. Schaeffer)

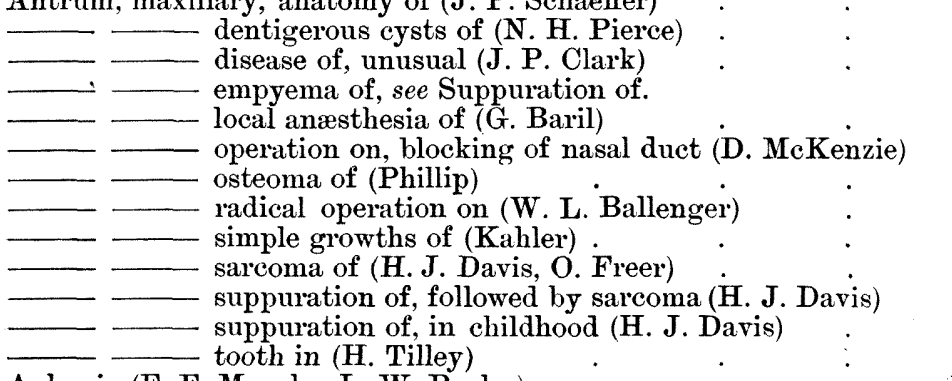

Aphonia (F. F. Muecke, L. W. Pegler)

A in a boy (W. J. Horne)

- recurrent (G. Catheart)

Arseno-benzol, see Salvarsan.

Arytænoid abscess, primary (Curtil)

Asthma, endoscopic treatment of (W. Freudenthal). nasal (Grossmann, Jay)

(P. Watson Williams) .
Auditory nerve, action of salvarsan upon (O. Beck, Benario, Desneux

$$
\text { and Dujardin, Gander and Guggenheim) }
$$

$317,608,499,500,501$

— acute posterior poliomyelitis affecting (J. R. Hunt) $\cdot 165$

- and multiple sclerosis (O. Beck) . . 219

$\begin{array}{ccc}- & 47 \\ - \text { angio-neuritic paralysis of (M. Farquharson) : } & : & 609\end{array}$ 
Austrian Otological Society

Brain, complication of frontal sinusitis (J. S. Fraser, J. D. Lithgow) $\quad$. 45

$\underline{\text { exposure of, through nasal sinuses, etc. (Onódi) }} \cdot 435$

- topography of (Onódi) . . . . . 435

- see also Frontal lobe, Temporo-sphenoidal lobe, etc.

British Medical Association, Birmingham Meeting, July, 1911

Bronchiectasis due to foreign body, removal (H. Tilley) $561,599,626 \mathrm{et} \mathrm{seq}$.

Bronchoscopy (P. Watson-Williams and A. J. M. Wright) 525

for foreign bodies (H. Tilley, D. C. Green, Casselberry) $211,276,319,525$

treatment of asthma by (W. Freudenthal) . . $\quad 537$

Bronchus, foreign body removed from (H. Tilley) : $\quad \vdots \quad$. 211

Caloric tests of posterior canal (Cheatle and Jenkins) $\quad \cdot \quad 92$

Canals, semicircular, external, fistula of (Bondy, W. Milligan, L. Sewell)

posterior, exposed (Cheatle and Jenkins)

$154,90,54$

Cancer, disappearance of, case of (R. H. Woods)

Carotid artery, internal, rupture of (F. Nuernberg) . . . . 554

Cerebellum, abscess of (Bárány, J. S. Barr, Ruttin, W. Milligan) 
Diphtheria antitoxin, death following (S. F. McKeen)

D carriers (A. G. Macdonald) . $\quad . \quad 384$

Diphtheritic paralysis (A. Love) . $\quad . \quad 5 \quad . \quad 565$

Ear and Throat Department, Royal Infirmary, Edinburgh, Reports for year 1909

$\cdot 57$

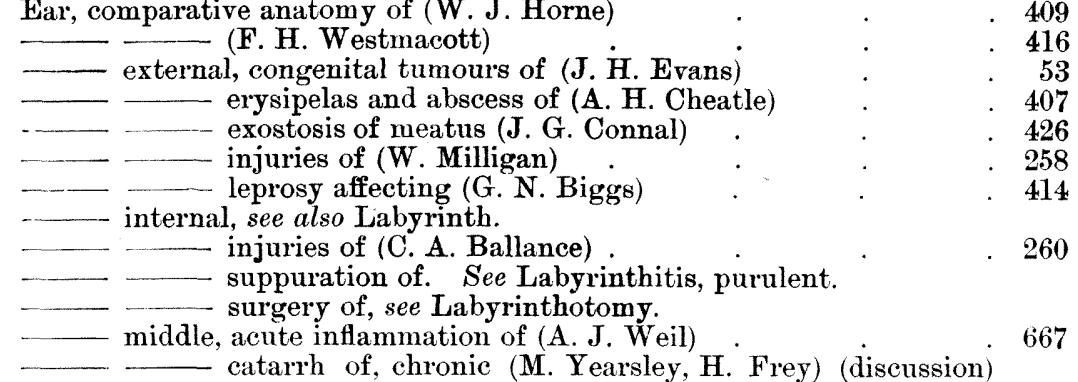
$626,633,643$

(disenssion)

chronic, adhesive processes of (M. Yearsley, H. Frey)

407

426

258

414

260

67

$626,633,643$

disease of, prevention (A. Bardes) $\quad \cdot \quad \cdot \quad 26,677$

exostosis of (A. Cheatle) : : : $\quad .93$

injuries of (W. Milligan, C. A. Ballance) $\quad 258,260$

neoplasm of (W. H. Kelson) 204

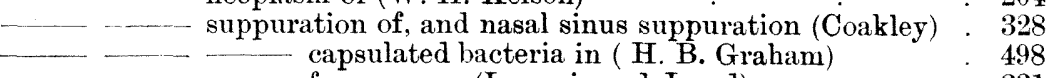

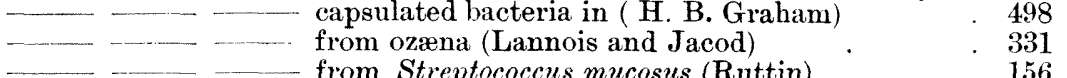

- - from Streptococcus mucosus (Ruttin) : $\quad .156$

Lactic acid for (Stepinski, Haskins) $\quad . \quad 165,498$
$-\quad$ meningitis : recovery (L. Turner)

$\begin{array}{ccc}\text { meningitis : recovery (L. Turner) } & 49 \\ \text { ossiculectomy for (H. Tod) } & \cdot & 109 \\ \text { silver nitrate in (G. L. Richards) } & \cdot & 53\end{array}$

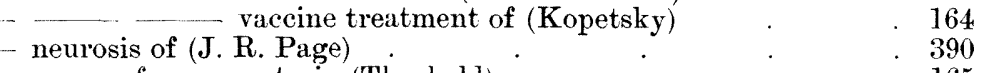

- from eye-strain (Theobald) $\quad: \quad \cdot \quad 165$

_- symptoms in general diseases (J. J. Kyle) : $\quad . \quad 112$

Edinburgh Royal Infirmary, Ear and Throat Department, Reports for the year $1909 \quad . \quad 5 \quad . \quad 57$

Ehrlich-Hata Remedy, see Salvarsan.

Emphysema, subcutaneous, of neck, after removal of tonsils (B.D.Parish) 275

Endoscopy, see Bronchoscopy, etc.

Epiglottis, epithelioma of (N. Patterson) . $\quad$. $\quad$. $\quad .143$

Ethmoid, bony cyst of ( $\mathrm{J}$. A. Thompson) . . . . 611

See also Turbinal, middle.

— carcinoma of (J. S. Barr) . . . . . . 376

- operation on ; orbital cellulitis after (A. J. M. Wright) $\quad .529$

- paralysis of third nerve after (A. J. M. Wright) $\quad .530$

- sareoma of, bilateral (W. Downie) . • . . . 372

Ethmoiditis, non-suppurative (W. B. Chamberlain) . $\quad . \quad 50$ visual fields in (G. F. C. Wallis)

Eustachian tube, deafness from cicatricial occlusion of (D. R. Paterson) 53

- development of (J. E. Frazer) . 53

Extra-dural abscess from frontal sinusitis (J. S. Fraser) $\quad: \quad \quad \cdot \quad 45$

- from primary mastoiditis (Halász) $\cdot \quad \cdot \quad \cdot 498$

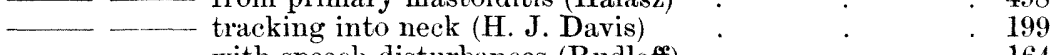

Fances, fibroma of (A. Bronner) . 
Fibrolysin in otolog (M. Yearley)

Fistula-symptom (R. Bárány) $\quad \cdot \quad \cdot \quad \cdot \quad 312$

Foreign bodies, see under Regions.

French Society of Largyngology, Otology and Rhinology . . 481

Frontal bone, necrosis of (W. Downie)

Frontal lobe of brain, otitic abscess of (P. Watson-Williams) $\quad . \quad 423$

Frontal sinus, see Sinus, frontal.

Glossitis, chronic (P. Watson-Williams) . $\quad$. $\quad$. $\quad 529$

Halle, University Aural Clinic at . . . . . . 204

Hay-Fever and Paroxysmal Sneezing (Vaso-Motor Rhinitis) (Eugene S. Yonge) (review)

Hay-fever, prophylactic inoculation for ( $T$, Noon)

Hearing after radical mastoid (C. M. Brown) $\quad{ }^{*}$

\begin{tabular}{ccc} 
effect of tobacco upon (H. O. Reik). &. &. \\
\hline & & 390
\end{tabular}

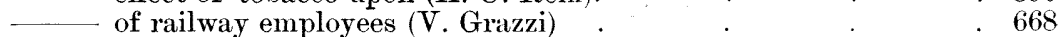

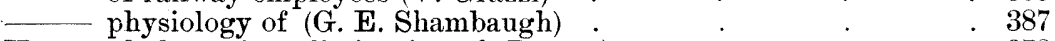

Hexamethylenamine, elimination of (Barton) . . . . $\quad 278$

Hints for the General Practitioner in Rhinology and Laryngology (Johann Fein) (review) . . . . 54

Hungarian Society of Physicians, the Royal; Section-Rhino-Laryngology .

Hypophysis, see Pituitary body.

Influenza of nose and throat, recurrent (G. L. Goodale) $\quad . \quad 105$

International Congress of Medicine at Budapest, Laryngological Section

$145,268,378,488$

Otological Sections; Officers .

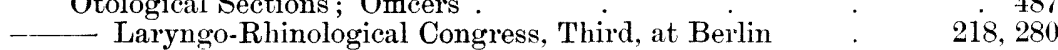

ogical and

- Otological Congress, Ninth _ . . . . . 519

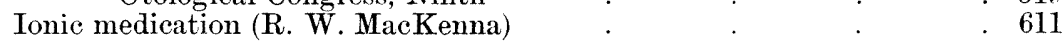

Journal of Laryngology, Rhinology, and Otology, The 113

Jugular bulb, operations on (G. Tiefenthal). . . 525

-
-

Labyrinth, see also Ear, internal.

effect of head-injury on (C. A. Ballance, Stenger)

- fistula of (Barany, Bondy, W. Milligan, S. Scott, L. Sewell)

___ necrosis of (F. H. Westmacott) _ . . . . . . 416

$\begin{array}{lll}\text { - semicircular canals of, see Canals, semicircular. } & \\ \text { suppuration of (Dortu) } & . & 6\end{array}$

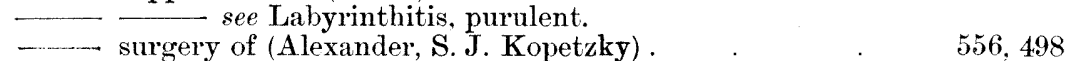

- syphilis of, in secondary stage (Hintze) . . $\quad .616$

- salvarsan in (O. Beck) . $\quad 316,317$

Labyrinthine vertigo, treated by operation (G. J. Jenkins) . . 411

Labyrinthitis, latent (J. Harper) . . . . . . $\quad .553$

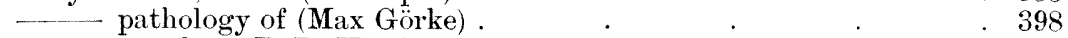

\begin{tabular}{llll} 
purulent (P. D. Kerrison) . &. &. &. \\
\hline
\end{tabular}

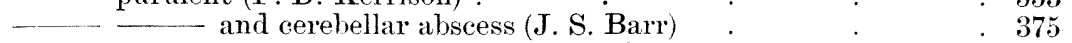

- fatal (J. S. Fraser) recovery (Ruttin) . . . . $\quad 314$

$\begin{array}{lr}\text { Labyrinthotomy (Bondy, W. Milligan, L. Bondy) } & 89,154 \\ - & \cdot\end{array}$

Laryngeal nerve, superior, injection of alcohol into (L. Turner) . 48

Laryngitis, chronic (W. Howarth) . . 304

- treatment of (T. J. Faulder) $\quad . \quad$. $\quad 42$ 


\section{Index.}

Laryngitis, typhoid (M. Paunz)

Laryngo-tracheal stenosis, treatment of (discussion) (V. Uchermann, etc.)

Laryngology, retrospect of

Laryngoscopy, direct (E. F. Ingals)

Larynx, see also Cords, vocal.

- abscess of, primary (Curtil)

cancer of (N. Patterson, L. H. Pegler, C. W. Richardson, P.

Watson-Williams) .

$143,139,320,208,526$

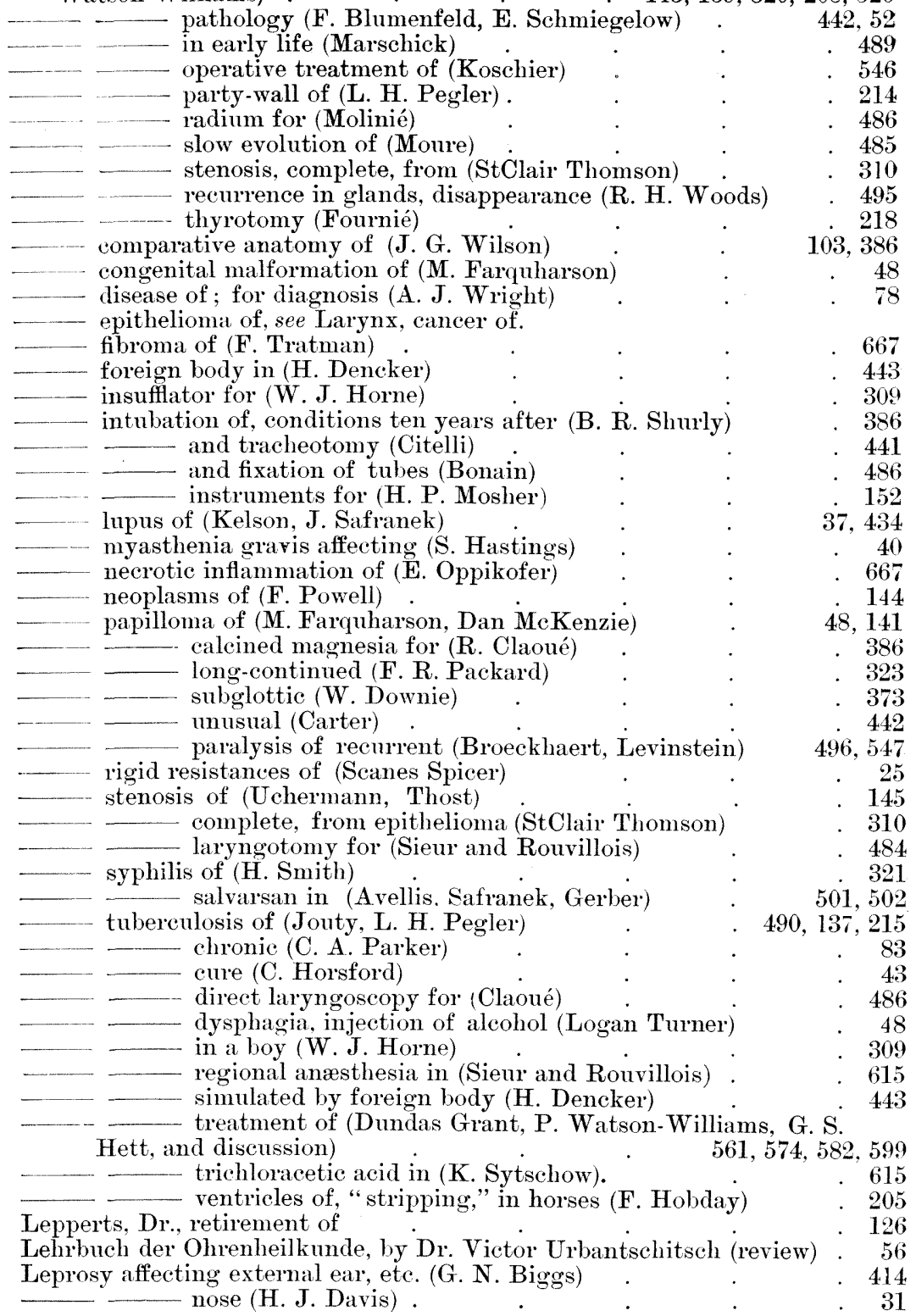


Lingual thyroid, see Thyroid gland, lingual.

Lip, chancres of, epidemic (J. F. Schamberg) diploëtic infantile; unilateral suppuration

Maxilla, superior, malformation of, unusual (H. Tilley)

Mediastinum, tumour of, death by asphyxia (Coakley)

"Medical Annual," The, 1910 (review) 1911 (review)

Membrana tympani, rupture of, in telephone operator (Veis) .

Ménière's syndrome, treated by operation (G. J. Jenkins)

Meningitis from middle-ear suppuration (D. W. Drury)

Mitral stenosis, recurrent paralysis in (Fetterolf and Norris)

Nasal duct, see Naso-lacrymal duct.

- obstruction, see Nose, obstruction of.

Naso-lacrymal duct, window-resection of (West) . . . . . $\quad 328$

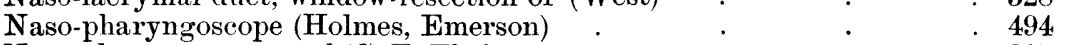

Naso-pharynx, cancer of (C. F. Theisen) : $\quad . \quad 5 \quad$. $\quad .317$ in girl, aged seventeen ( $\mathrm{T}$. Guthrie) . $\quad . \quad 449$ \begin{tabular}{lr} 
catarrh of, chronic, bacteriology of (C. E. West) $\quad \cdot$ & $\cdot$ \\
\hline
\end{tabular} high frequency for (David) . $\quad . \quad 546$ epithelioma of (E. Law)

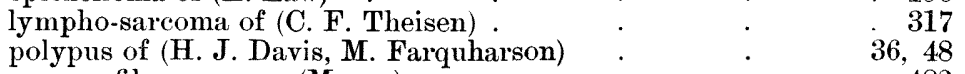
fibro-mucous (Moure)
fibrous (W. B. Chamberlain, Walker Downie, W. H.

Kelson, W. A. Wells) 


\section{Index.}

Nerves, cranial, in tabes dorsalis (W. Williams) $\quad . \quad 5 \mathbf{P A R}$

See also Vestibular apparatus.

Neurasthenia, nasal phenomena of (C. P. Grayson) . 101

Neuro-recurrence after salvarsan (Benario, Desneux and Dujardin $\mathbf{H}$. Gander) See also Vestibular apparatus.

Nodes, singer's', galvano-cautery for (E. A. Peters, C. J. Koenig) 41, 330

Nose and throat, diseases of the (StClair Thomson) (review) . $\quad 671$ cancer of (W. Stnart Low) . . . . . $\quad .50$ \begin{tabular}{lll}
- & & \\
\hline
\end{tabular}

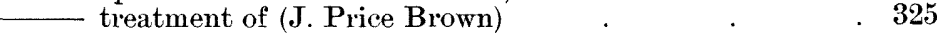
catarrh of, acute, see Rhinitis. circulation of, connection with dura and orbit (G. E. Shambaugh) 105 deformity of, treated by paraffin (W. Downie) . . 371 diseases of, injuries of the head and (Ziem) - intra-cranial complications of (Frendenthal, Onodi) $\quad . \quad 379$ - radium in ('T. G. Ouston) . $\quad 505$ - relation to tuberculosis (Faracci) . $\quad 491$

- - to oculo-orbital diseases (Baumgarten, Coffin, Cun-

ningham, Frankenberger, StClair Thomson, Wallis) 160, 272, 338, 439, respiration (P. Watson-Williams) 617 irrigation for (Guthberlet) . . . . 276 lateral wall of, development of (J. P. Schaeffer) . $\quad 662$ leprosy of (H. J. Davis) . . 31 leukæmia causing abscesses of (Tunis) . $\quad 385$ lupus of, ionic medication for (R. W. MacKenna) . 611 - Rouge's operation for (M. Farquharson) . $\quad 47$ myxoma of (Hajek and Polyak) . $\quad 150$ neoplasm of (W. J. Horne) . . . . . 309 neurasthenic phenomena in (C. P. Grayson) . . 101 obstruction of, effects (R. Palleine) _ . $\quad . \quad 549$ physiology of (J. Adam) . . . . . . 288 polypus of ; choanal (Láng) - fibrous (Jacques and Bertemès) - from inferior turbinals (J. Adam) \begin{tabular}{cr} 
malignant transformation of (H. J. Davis) & 34 \\
\hline & 105
\end{tabular} reflex of, during anæsthesia (J. Blumfeld) $\quad . \quad 493$ reflex nemroses of (W. S. Bryant) . . . . $\quad 390$ sarcoma of, external operation (W. S. Syme) $\quad . \quad 429$ septum of, deviations of (D. M. Officer) . . . 610 papilloma of ( $\mathrm{H}$. Arrowsmith) $\quad 440$ 
Nose, vestibule of, primary chancre of ( $N$. Patterson) retention cyst of (Logan Turner) . . . $\quad .48$

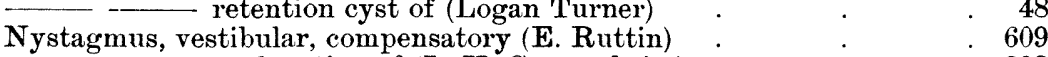

- explanation of (L. K. Guggenheim) $\quad . \quad$. $\quad . \quad 388$

Ocular symptoms produced by nasal disease (E. Baumgarten, L. A.

Coffin, H. H. B. Cunningham, StClair Thomson, O. Frankenberger,

G. F. C. Wallis), (discussion) 160,612, 272, 388, 439, 531, 242, 511, 531

CEsophago-gastroscope (W. Hill) . . . . . 82, 134, 525

Esophagoscope with expanding blades (W. Hill) . $\quad$. $\quad 82$

Esophagoscopy, experiences (S. H. Large). $\quad . \quad$. 330

(Esophagus, cancer of (W. Hill, C. Watson-Williams) $\quad$. $\quad 307,143$

- radium in (C. Watson-Williams, C. Hope and N. S.

- Finzi) temporary cure ( $\dot{W}$. Hill)

Optic neuritis and ophthalmoplegia externa from sphenoidal disease

(H. J. Davis) . . . . . . . . 33 benefited by operation (H. Smith) $\quad . \quad 653$

Orbital cellulitis after ethmoidal operation (A. J. M. Wright) . $\quad$. $\quad 529$

Ossiculectomy, value of (Hunter Tod) . . . . . 109

Otic element of arctic whale (F. H. Westmacott) $\quad . \quad \cdot \quad . \quad 416$

Oto-larnygology, the teaching of (S. MacCuen Smith and discussion) . 658

Otosclerosis (G. Brühl, O. Mayer) . . . . 294, 496

$\begin{array}{llllllll} & \text { - histology of }(\mathrm{O} \text {. Mayer }) & \text {. } & \text {. } & & & 497\end{array}$

\begin{tabular}{llllll} 
- literature of (Froschels) & l &. &. & & \\
\hline
\end{tabular}

- pathology and situation of (G. Ferreri) $\quad . \quad$. $\quad 109$

- traumatic (E. Ruttin) . $\quad 316$

Otology, retrospect of . . . . . $\quad 20$

Otorrhoea, see Ear, middle, suppuration of.
Ouston (T. G.), obituary notice . $. \quad . \quad 560$

Ovo-œsophago-gastric tube, permanent styletted (W. Hill) . . $\quad$. 307

Ozæna, see Rhinitis, atrophic.

Palate, deficiency of, congenital (W. Downie) $\quad 374$

- deformity of, with displaced pituitary body (A. Tweedie) $\quad 80$

endothelioma of, treated with radium (J. G. French) . $\quad .209$

- epithelial pearls of, and tumours (Di Colo) . . . . 491

\begin{tabular}{llll} 
& & & \\
\hline
\end{tabular}

$\begin{array}{llll}\text { - soft adeno-carcinoma of (Cornet) } & . & . & .\end{array}$

- - paralysis of (W.S. Syme) . . . . . 431

- perforation of (W. J.Horne) . . . 309

- nystagmus of (W. G. Porter) . . . $\quad 44$

Paraffin, injection of, for nasal deformity (W. Downie) . . . $\quad 371$

Parotid, cystic adenoma of (W. Stuart-Low) $\quad . \quad 82$

$\begin{array}{lllll}\text { Pemphigus (W. Watson-Williams) } & . & . & 528\end{array}$

Periotic bones of fossil Cetacea (W. J. Horne) . $\quad . \quad 409$

Peritonsillar abscess, death from (S. W. Prowse) . . . . $\quad 664$

\begin{tabular}{lllll} 
& & & \\
\hline
\end{tabular}

Pharyngitis, lateral (Schubiger) $\quad . \quad 5 \quad . \quad$. $\quad . \quad 325$

Pharyngoscope, Hay's improved (H. Tilley) $\quad . \quad$. $\quad 303$

Pharynx, cancer of (M. Farquharson, P. R. W. de Santi) : $\quad 47,307$ cancer of deep (W. Hill) . . . . . . 44

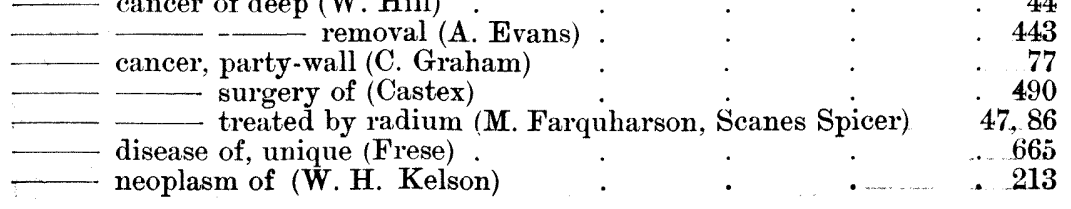




\section{Index.}

Pharynx, papilloma of (E. C. Catheart) pemphigus of ( $\mathrm{P}$. Watson -Williams) reflex neuroses of (W. S. Bryant) sporotrichosis of (Duvergie and Bain) syphilis of, tertiary (P. Watson-Williams) syphilitic stenosis (Ingersoll, Prota) ulceration of, extensive (L. H. Pegler) from pyorrhøa (L. H. Pegler)

Phonation, centres for (Katzenstein)

Poliomyelitis, epidemic (W.S. Bryant)

Quinine and urea hydrochlorate as local anæsthetic (G. Fletcher Ingals)

Quinsy, see Peritonsillar abscess.

"Radiography of the Mastoid Process and of the Nasal Accessory Sinuses, Photographic Atlas of " (Joseph Beck) (review) .

- in diseases of the nose and throat (Freudenthal, T. G. Ouston)

- in osophageal cancer (W. Hill, Finzi and Hope)

Rectal feeding, value of (W. L. Brown)

Remedies, a Practical Guide to the Newer (J. M. Fortescue Brickdale) (review)

_ New and Non-official, 1911 (review)

Reports for the year 1909 from the Ear and Throat Department of the

Royal Infirmary, Edinburgh (A. Logan Turner).

Respiration, influence of upper air-tract on (P. Watson-Williams) : 617

Retropharyngeal abscess, anæsthesia for (R. Gill) . . . . 384

Retropharynx, embryonic cysts of (Onódi) . $\quad: \quad 434$

Rhinitis, atrophic (J. Adam, J. S. Fraser, and F. E. Reynolds) $\quad 377,169$

$\begin{array}{rr}- & 331 \\ \text { and otitis media (Lannois and Jacod). } & .\end{array}$

_ early stages of (Baumgarten) $\quad . \quad 5 \quad 270$

—_ - treatment (Siems) . $\quad \cdot \quad \cdot \quad \cdot 487$

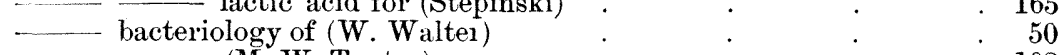

— caseosa (M. W. Taptas) . 108

- of scarlet fever, bacterin treatment (Kolmer and Weston) : $\quad 662$

vaso-motor, see Rhinorrhoa, vaso-motor.
Rhino-laryngology and general medicine (H. Arrowsmith) $\quad . \quad ~$

Rhinology, retrospect of . $\quad . \quad \cdot \quad 16$

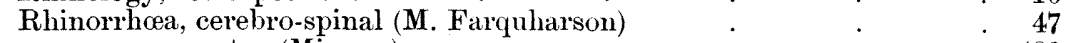

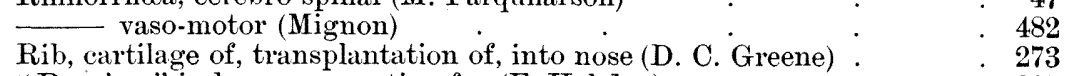

"Roaring" in horses, operation for (F. Hobday) . $\quad . \quad 205$

Rosenmuller's fossa and the middle ear (M. Yearsley) $\quad$ : $\quad$ : 331

"Rouge's operation" for nasal lupus (M. Farquharson) : $\quad . \quad 47$

Royal Society of Medicine, Proceedings of the Laryngological Section 
"606," see Salvarsan.

Salivary glands, diseases of (discussion)

Salvarsan (Benario, etc.) . deafness after (O. Beck) effect upon labyrinth (G. Alexander, Benario, etc.) in congenital syphilis (J. L. Bunch) in diseases of larynx (G. Avellis)

in syphilis of nose (G. N. Biggs, Gerber, Safranek) instruments for injection of (Lieven) Treatment of Syphilis by (review)

Scleroma, clinical aspect (Neumann) distribution of (Irsaï. Schrötter)

Scottish Otological and Laryngological Society

Sea-sickness, causation of (Bárány)

Semicircular canals, see Canals, semicircular, and also Vestibular apparatus.

Semon Lectureship in Laryngology Sir Felix, memorial to

Septum nasi, see Nose, septum of.

Singer's nodes, see Cords, vocal.

Sinus frontal, endothelioma of (N. Maclay). \begin{tabular}{lll}
\hline $\begin{array}{l}\text { intra-nasal drainage of ( } \mathbf{F} \text {. Ingals) } \\
\text { puncture of (Sieur and Rouvillois) }\end{array}$ & $\cdot$ \\
\hline spongification of (Preysing) & $\cdot$ \\
Wright).
\end{tabular} Killian's operation for (J.S. Fraser, R. Fullerton, W. S. Syme) treatment of (J. S. Barr, J. Moore, Stuart-Low, StClair Thomson, Weil, P. Watson-Williams (discussion) $354,355,356,357,376,380$ with cerebral involvement (J. D. Lithgow) \begin{tabular}{cr}
- with cerebral involvement (J. D. Lithgow) & 45 \\
\hline & Watson-Williams operation (Watson-Williams) \\
\hline & 526 \\
with extra-dural abscess (J. S. Fraser). & 45
\end{tabular} with necrosis of frontal bone (W. Downie) $\quad . \quad 374$ lateral, thrombosis of (J. G. Connal, J. Kerr Love, W. C. Nourse, J. W. Wood) prostatic abscess (J. $\dot{\text { G. French) }}$

sigmoid, see Sinus, lateral.

sphenoidal, suppuration of, eye symptoms (H. J. Davis, G. F. C.

Wallis)

Sinuses, accessory, exostoses of (H. $\dot{\mathrm{P}}$. Mosher)

Coffin, Cunningham, Frankenberger, StClair Thomson, G. F. C. Wallis, Watson-Williams) $160,272,242,338,439,511$

- suppuration of, and acute otitis media (Coakley) 558, 328

-1 in scarlet fever (T. Hubbard) . $\quad 657$

- brain, complications of (Onodi) $\quad . \quad 379$

$-\ldots$ treatment of (Hajek) $\quad . \quad 378$

vaccine treatment (Burkett and Meakins) . 163

Sinusitis, anterior nasal visual fields in (G. F. C. Wallis) . . 511

Sixth cranial nerve, paralysis of, otitic (L. Leto) $\quad . \quad$. $\quad 616$

Specialists, education of (C. M. Cobb) . $\quad . \quad 278$

Speziellen Chirurgie des Ohres, etc., Handbuch der (Drs. Katz, Preysing and Blumenfeld) (review) . . . $\quad .503$

Spheno-palatine ganglion, syndrome of neurosis of (G. Sluder) $\quad . \quad 151$

Submucous resection, see Nose, septum of.

Surdus in Search of his Hearing: An Exposure of Deafness Quacks (Evan Yellon) (review) 


\section{Index.}

Syphilis, Treatment of, by the Ehrlich-Hata Remedy (review) . $\quad{ }_{112}^{\text {PAGE }}$

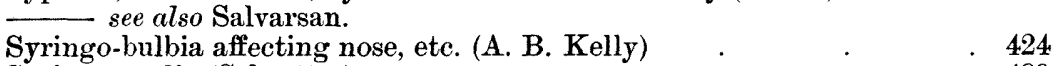

$\begin{array}{lllll}\text { Syringomyelia (Schrötter) } & . & . & . & 489\end{array}$

Tabes dorsalis, cranial nerves in (W. Williams) $\quad . \quad$. $\quad .559$

Teeth, the, and diseases of mucous membranes (W. K. Sibley) . 437

Telangiectasis of mouth, etc. (J.Safranek) . . . . 433

Temporal bone, types of fracture of (A.H. Cheatle, G. J. Jenkins) $\quad$ $\quad 267$

Temporal lobe, see Temporo-sphenoidallobe.

Temporo-sphenoidal lobe, abscess of, (Pommerehne) . $\quad$. $\quad 669$

- operation, patient twenty-four years after (T. Barr) 371

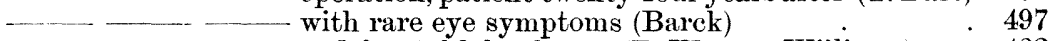

\begin{tabular}{ccc}
- & 423 \\
\hline & tumour of, misleading symptoms (Ruttin) &.
\end{tabular}

Thrombo-kinase, hæmostatic (L. W. Strong). $\quad . \quad 560$

Thyro-fissure, see Thyrotomy.

Thyro-lingual cyst, removal of, acute thyroidism (H. J. Davis) $\quad 33$

Thyroid cartilage, wounds of, cicatrisation of (Strazza) $\quad$. 147

gland, diseases of, and the upper respiratory tract (R. S. Burt) $\quad 558$ $\begin{array}{ccc}\text { gland, diseases of, and the upper respiratory tract (R. S. Burt) } & 558 \\ \text { suppuration of (I. Bahri) } & . & 558\end{array}$ lingual (G. W. Badgerow, Bertein and Gellé) $\quad$. $\quad 142,550$ (H. F. Smyth)

Thyrotomy, cicatrisation after (Strazza) . $\quad . \quad 147$

for papilloma (F. R. Packard, W. Downie) 323, 373

Tobacco deafness (Reik) . . . . . $\quad$. 390

Tongue, black (C. H. Knight) . $\quad .324$

Tonsil, cancer of, cured by operation (M. H. Richardson) $\quad$. $\quad$. 665 sarcoma of, in a child (L. C. Cline) . . . . 665

Tonsils, enucleation of (J. S. Fraser) $\quad . \quad 663$

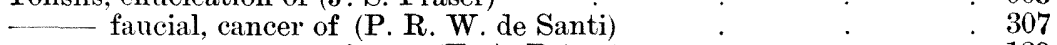

$-139$

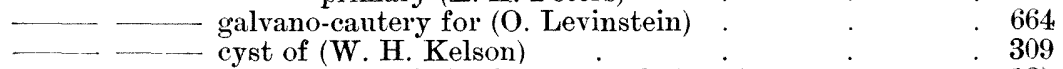

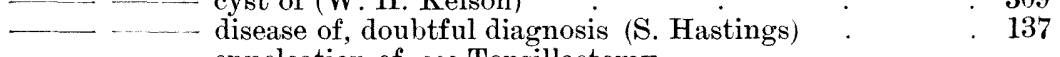

$\begin{array}{ll}- & \\ - & \text { enucleation of, see Tonsillectomy. }\end{array} \quad 452$

-

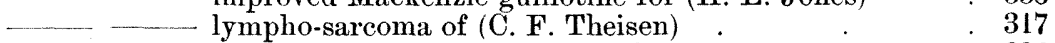

\begin{tabular}{lll} 
& & 326 \\
\hline & operations on, choice of (G. A. Crockett) & 326
\end{tabular}

-1 followed by Basedow's disease (C. J. König) : 275

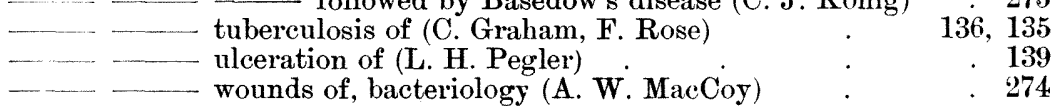

pharyngeal, see Adenoids.
Tonsillectomy (H. Arrowsmith, Blegvad, Freedman, K. Kofler) 390, 326, 495,

hæmorrhage after (H. A. Barnes) . . . . . 274

Tonsillitis due to Bacillus coli (C. B. Faunce) $\quad . \quad$. $\quad$. 494

$\begin{array}{llll}\text { Tonsillolith (C. A. Parker) } & \text {. } & 36\end{array}$

Trachea, fatal pressure on, by tumour (C. G. Coakley) $\quad$. $\quad 322$

$\begin{array}{lll}\text { foreign body in (Clark and Richardson) } & \text {. } & 276\end{array}$

\begin{tabular}{llll}
- gumma of, death from (McCardie) &. &. &. \\
\hline
\end{tabular}

- stenosis of, dilatation (P. Laurens) . $\quad . \quad . \quad . \quad . \quad 485$

Tracheo-bronchoscopy (S. H. Large) $\quad . \quad$. $\quad . \quad 330$

Tracheo-laryngostomy for stenosis (W. Hill) $\quad . \quad . \quad . \quad . \quad 304$

Trauma in relation to otology (discussion) $\quad . \quad . \quad . \quad 258$

Treatment of Syphilis by the Ehrlich-Hata Remedy, The (Dr. J. Bressler) (review) 
Turbinal bone, middle: cyst of (H. Gaudier, P. Watson-Williams) $\quad 493,529$ Turbinated bodies and sinuses, function of (J. Adam) $\quad . \quad 288$ Typhoid deafness (P. Manasse) . $\quad . \quad$. $\quad . \quad . \quad 111$

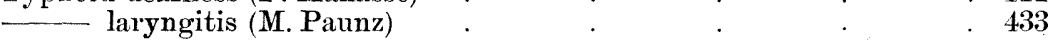

Urea-hydrochlorate and quinine as local anæsthetic (E. F. Ingals) 106 Uvula, pedunculated growth on (H. Tilley)

Vaccine treatment (discussion) . $\quad . \quad . \quad . \quad 318$

of accessory sinusitis (Burkett and Meakens) . $\quad$. 163

- of middle-ear suppuration (Kopetsky) . . . 164

—_- of pyorrhoa alveolaris (Williams) . . . . $\quad .552$

Vertigo, acute of scarlatinal rhinitis (Kolmer and Weston)

Vertigo, acute, case of (H. J. Davis) 199

- labyrinthine, non-infective, operation for (G. J. Jenkins) . 411

- researches (von Stein) · tube (E M. Holmes) · $\quad 445$

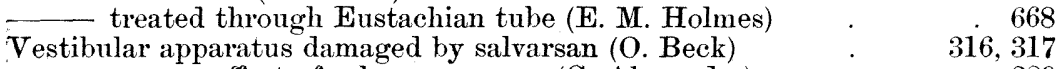

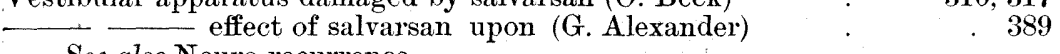
See also Neuro-recurrence.

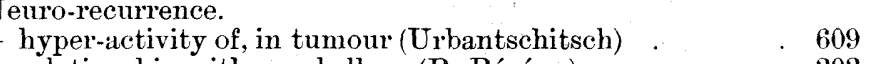

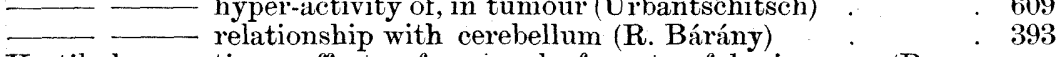

Vestibular reactions, effects of removal of parts of brain upon (Baner and Leidler) . $\quad . \quad . \quad 669$

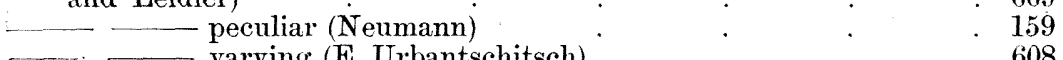

See also Nystagmus, vestibular, and Canals, semicircular. $\quad \cdot \quad \cdot 608$

Vision, impairment of, from intra-nasal disease (E. Baumgarten) $\quad . \quad 160$

Visual fields in anterior nasal sinusitis (G. F. C. Wallis) . 511 in sphenoid and ethmoid sinusitis (G. F. C. Wallis) . 242 See also Ocular symptoms, etc. Bouyer, Fils, (review) $. \quad . \quad . \quad . \quad 279$ See also Phonetics.

Wire saw in radical mastoid (V. S. Stein) . $\quad . \quad$. $\quad$. 123

X-rays, see Radiography.

\section{AUTHORS.}

ADAM (James), atrophic rhinitis. hearing after mastoid operation odema of face polypi from inferior turbinals turbinal and sinus function

Alexander (G.), labyrinth surgery - - salvarsan

A Rrowsmith (H.), septal papilloma tonsil enucleation

Avelurs (Georg), salvarsan

BADGERow (Geo. W.), lingual thyroid BAHRI (Ismet), thyroiditis

Ballance (C. A.), injuries of ear .

BALLENGER (W. L.), antrum operation

BÁRÁNY, alcohol intoxication 
BÁRÁNy (Robt.), cerebellum and vestibular apparatus

- labyrinth fistula . .

BARCK, brain abscess

Bardes (A.), prevention of ear disease

BARIL (G.), regional anæsthesia.

Barnes (H. A.), tonsillotomy

BARR (J. Stoddart), cerebellar abscess

‥ ethmoidal cancer

- frontal sinus operation

BARR (Thos.), temporo-sphenoidal abscess

Barton, hexamethylenamine

BAUER (J.), and LEIDLER (R.), vestibular reflexes
BaUMGarTEN, early ozæna

BAUMGARTEN (E.), impairment of vision, ete.

BECK (J. C.), mastoid operations. salivary glands

BEcK (Oscar), deafness after salvarsan multiple sclerosis - salvarsan

Bertein (P.), and Gelí丶 (E.), lingual thyroids

Benario, neuro-recurrence after salvarsan .

BigGs (G. N.), leprosy salvarsan

BLACK (N. M.), nasal stenosis

Blegvad, tonsillectomy.

Bud Menfeld (Felix), laryngeal cancer

Blumfeld (J.), nasal reflex

BonaIN, intubation

BONDY, labyrinthitis

BoURACK, adenoid operations

BresGen (M.), electrolysis

BRINDEL, synechiæ of nose

Bronner (Adolph), faucial fibroma

Brown (Clayton M.), radical mastoid

BRown (G. V. J.), maxillary readjustment .

Brown (W. Langdon), rectal feeding

BRÜHL (Gustave), otosclerosis

Bryant (W. Sohier), epidemic poliomyelitis
reflex neuroses .

Bucklin (C. A.), pulmonary tuberculosis, etc.

BunCH (J.S.), salvarsan

BurketT (H. S.), and Mearins (j. C.), vaccine treatment

BuRT (Shurley R.), thyroid gland.

Carter (W. W.), laryngeal papilloma transplantation of bone, etc.

Casselberry (W. E.), bronchoscopy

Castex, pharyngeal cancer

Cathcart (E. C.), acute mastoiditis papilloma of pharynx recurrent aphonia ulceration of vocal cord.

Chamberlain (W. B.), naso-pharyngeal fibroma 
Cheatre (A. H.), and Jenkins (G. J.), exposed posterior semicircular canal

CHIARI, ethmoidal fibroma

Crtelli, adenoids and the hypophysis intubation

Chaoué (R.), papilloma of larynx

laryngeal tuberculosis

Clark (J.P.), maxillary antrum disease and RrcharDson (O.), foreign body in trachea

Curne (L. C.), sarcoma of tonsil

COAKLEY (C. G.) mediastinal tumour sinus suppuration, etc.

Coвв (C. M.), education of specialists

Colo (Di) palatal tumours

ConNaL (J. Galbraith), exostosis of ear lateral sinus thrombosis

Coffin (L. A.), sinusitis and eye symptoms

CoRnET, epithelioma of palate

CrocketT (E. A.), tonsil operations

CUNNINGHAM (H. H.), nose and eye

CurTIL, arytænoid abscess

David, high frequency

DAvis (H.J.), extra-dural abscess - mastoiditis maxillary antrum suppuration in childhood nasal leprosy naso-pharyngeal polypus. sarcoma of antrum thyro-lingual cyst vertigo

De Santi (P.R. W.), cancer of pharynx

Delaran (D. B.), motor-car

DENCKER (H.). foreign body in larynx

DESNEUX and DUJARDIN, neuro-recurrence after salvarsan

Donelan (J.), nasal speculum swelling of vocal cord

Dortu (P.), cerebellar abscess

DownIE (Walker), bilateral abductor paralysis congenital deficiency of palate

DownIE (Walker), ethmoidal sarcoma - naso-pharyngeal polypus. - necrosis of frontal bone paraffin injections

- - subglottic papilloma

Duvergie (J.) and BaIN (A.), sporotrichosis

Evans (Arthur), pharyngeal cancer

Evans (J. Howell), congenital auricular tumours

FABRI (E.), iodo-thiosinamine

Faracci, tuberculosis

Farquharson (Malcolm), choanal polypus cerebro-spinal rhinorrhoea. epithelioma of pharynx lupus of nose

papilloma of larynx

paralysis of acoustic nerve

FAulderR (T. Jefferson), chronic laryngitis

FaunCe (C. B.), colon bacillus tonsillitis

Fern, resection of septum 
Fetterolf and NorRIS, recurrent paralysis . . . . 552

Finzi and Hope (C. W. M.), csophagoscopy and radium . . . 525

Flata U (T. S.), singers' nodes . . . . . . 553

Fournite, cancer of larynx ․ . . . . . . . 218

Frankenberger $(O$.$) , ocular disturbances, ete. \quad . \quad$. $\quad .439$

Fraser (J. S.), enucleation of tonsils . . . . . . . . 663

frontal sinusitis, extra-dural abscess $\quad . \quad 45$

Killian's operation $\quad . \quad$. $\quad . \quad 47$

purulent labyrinthitis . . . . . $\quad . \quad 46$

and REYNoLDS (F. E.), ozæna $\quad$. $\quad$. $\quad$. 169

Frazer (J. E.), development of Eustachian tube . . . . $\quad 53$

Freedman, tonsillectomy $\quad . \quad$. $\quad . \quad$. $\quad .495$

FreER (O.), antral sarcoma $\quad . \quad$. $\quad . \quad$. . . $\quad .440$

French (J. Gay), endothelioma of palate : $\quad . \quad 209$ - lateral sinus thrombosis . . . . . . 520 esophageal stricture . . . . . 37

Frese (Prof.), unique disease of mouth . . . . . $\quad 665$

Freudenthal (Wolff), asthma . . . . . . . 537

intra-cranial complications $\quad . \quad 5 \quad$. $\quad .379$ radium . . 611

FrEY, (H.), chronic adhesive processes of middle ear

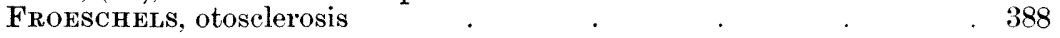

Galiaher (T. G.), frontal sinus operation . . . . . 656

GaRDINER (W. T.), statistical tables . . . 114

Gavdier (H.), middle turbinal cyst $\quad . \quad$. $\quad . \quad 493$

C and GUGGENheim (H.), salvarsan . . 501

GERBER, salvarsan . . . . . . . 502

GILL (Richard), retro-pharyngeal abscess . . . . . 384

GOODALE (J. L.), influenza . . . . . 105

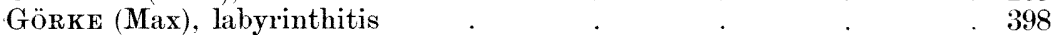

GraHam (Cecil), pharyngeal cancer $\quad . \quad$. . $\quad .77$ - tonsillar tuberculosis $\quad . \quad$.

GraHAM (H. B.), acute otitis

GRANT (Dundas), laryngeal tuberculosis : . . . . 561 Prof. Lucae . 281 (reviews) $\quad 54,55,56,112,167,223,278,279,332,448,503$

Grayson (C. P.), neurasthenia . . . 101

GrazzI (V.), hearing of railway employés . $\quad .668$

Green (D. Crosby), bronchoscopy . . . . . $\quad 276$

- transplantation of rib, etc. . . . . 273

Grossard and KaUFManN, adenoidectomy : . $3\ulcorner 3$

GrossmanN, nasal asthma . . . . . . 268

GUGGENHEIM (L. K.), vestibular nystagmus : . $\quad 388$

GUTBERLET (W.), nasal irrigator . . . . . . 276

GUTHRIE (Thos.), cancer of naso-pharynx : $\quad$. $\quad . \quad 449$

GUYot (F.), anæsthesia for adenoids : .

HAJEK, sinus suppuration $\quad . \quad$. $\quad . \quad$. $\quad$. 378 and PoLÝ́K, nasal myxoma . . $\quad 150$

Halísz (H.), extra-dural abscess . $\quad . \quad$. $\quad . \quad 498$

Halle (Max), alæ nasi . . . . . . . . 348

HARPER (Jas.), latent labyrinthitis . . . . . . 553

HASKin (W. H.), suppuration of middle ear . . . . 498

HASTINGS (Somerville), burr for nasal antrostomy . . . 217 myasthenia gravis $\quad . \quad . \quad 49$ tonsillar disease.

HEATH (C. J.), mastoid operation . $\quad . \quad$. . . . 417

HELD (R. Johnson), salivary glands $\quad . \quad$. . . 476

Hetr (G. Seccombe), laryngeal tuberculosis . . . 582 


\section{Index.}

HILL (Wm.), cancer of œsophagus cancer of pharynx

nasal tuberculosis

- œsophagoscope with expanding blades

cesophago-gastroscopy

tracheo-laryngostomy

and HerscheLL (G.), esophago-gastroscopy

Hintze (K.), labyrinth syphilis

HовDA (F.), ventricle-stripping, etc.

HoFFMANN (R.), maxillary eysts .

Holmes (E. M.), cure of vertigo naso-pharyngoscope

HoNEIJ, common colds

HOR NE (W. Jobson), aphonia

-___ fossil periotic bones

- insufflator

- neoplasm of nose

- - perforation of soft palate

tuberculosis of larynx

HoRsFord (C.), laryngeal tuberculosis

How ARTH (Walter), chronic laryngitis

HUBBARD (Thos.), scarlatinal sinus suppuration

Hunt (J. Ramsay), poliomyelitis, etc.

Ingals (E. Fletcher), direct laryngoscope frontal sinusitis local anæsthesia

INGERSOLL, syphilitic pharyngeal stenosis :

IRsAI, scleroma

$J_{A C Q U E S}$ and BeRTEMìs, fibrous polypus

$\mathrm{J}_{\mathbf{A Y}}$ (Melville), asthma.

JENKINS (G. J.), fractures of temporal bone

Ménière's syndrome, operation

and Cheathe (A. H.), exposed posterior semicircular canal

Jones (H. E.), tonsil guillotine

Joutr, laryngeal tuberculosis

KaHLER, antral neoplasms

Katzenstein, phonation centres.

Keгтн (Prof.), remarks on displaced pituitary

KeLLY (A. Brown), myasthenia gravis

- syringobulbia

KeLson (W. H.), lupus of larynx

neoplasm of pharynx

neoplasm of tympanum

polypus of naso-pharyin

tonsillar eyst

Kerrison (Philip D.), purulent labyrinthitis

KNIGHT (C. H.), black tongue

KoenIG (C. J.), singer's' nodes tonsillotomy, etc.

KOFFLER (Karl), tonsillectomy

Kolmer and Weston, searlatinal rhinitis

Kopetsky (S. J.). labyrinth surgery

- vaccine therapy in otitis

KYLE (J. J.), ear symptoms in general disease

PAGE

43,307

44

145

82

$82,134,307$

304

525

. 616

205

550

668

494

492

217

409

309

309

309

309

43

304

657

165

536

379

106,278

273

. 488

483

493

267

411

92

335

490

489

548

80

425

424

37

213

204

84

309

553

324

330

275

326

662

498

164

112

LabourÉ (J.), adenoids

LACK (H. Lambert), lupus erythematosus of mouth 492 
Lan NoIs and JocoD, ozænatous otitis

LARGE (Seccord H.), tracheoscopy, etc.

LaUtmann, adenoid operation nasal syphilis

Laurens (P.), tracheal stenosis:

LAW (E.), epithelioma of naso-pharynx

LETo (L.), paralysis of sixth nerve

LEVINSTEIN (O.), chronic tonsillitis recurrent paralysis

Lreven, salvarsan

LithGow (J. D.), frontal sinusitis

Logan (J. E.), President's Address

Love (A.), diphtheritic paralysis

Love (J. Kerr), education of the deaf lateral sinus thrombosis

Löwe (Ludwig), nasal surgery

MCCARdie (W. J.), tracheal gumma

MACCoY (A. W.), tonsil operation

Macdonald (A. G.), diphtheria carriers

MacKenna (R. W.), ionic medication

McKeEN (S. F.), death following diphtheria antitoxin

McKenzie (Dan), blocking of nasal duct.

_- laryngeal papilloma

___ obliteration of naso-pharynx - (review)

- unilateral deafness

MACLAY (Neil), endothelioma of frontal bone

MAHU (Georges), partial mastoid operation

Manasse (P.), typhoid deafness.

MARSCHICK, laryngeal cancer

Mathewson (G. H.), mastoiditis .

Mayer (Emil), cesophageal diverticula

Mayer (O.), otosclerosis

Meakins (J. C.), and BuRKetT (H. S.), vaccine treatment

Merrill (W. H.), diabetic deafness

Metzenbaum (M.), submucous resection

Meyer (A.), adenoids

Miluigan (W.), cerebellar abscess

- injuries of external and middle ear .

labyrinth fistula.

labyrinth operation

Mignon, spasmodic rhinitis

MOoRe (Irwin), frontal sinusitis

MOSHER (H. P.), intubation of larynx - sinus exostosis

Moure, cancer of nose

- laryngeal cancer . naso-pharyngeal polypus

Mouret, dehiscences of ear, etc.

MUecke (F. F.), aphonia

MyLes (Robert C.), salivary glands

NAtier (Marcel), ozæua

Neumans, deafness for conversation scleroma

Noon (L.), hay-fever

Noursf (W. Chichele), lateral sinus thrombosis

Nuernberg (F.), rupture of carotid 
OFficer (D. McM.), septal deviation

ONODI (A.), embryonic cysts exposure of brain, etc. intra-cranial complications recessus frontalis

OPPIKOFER (E.), gangrene of larynx, etc.

Ouston (T. G.). radium .

Packard (F. R.), laryngeal papilloma

PAge (J. R.), reflex neuroses

Palleine (Robert), nasal obstruction

Parish (B. D.), subcutaneous emphysema, etc.

Parker (Chas. A.), tonsillolith

Patterson (Norman), epiglottic cancer denture in csophagus - nasal chancre

Paunz (M.), typhoid laryngitis

Pegler (L. H.), aphonia in a boy . cancer of larynx

laryngeal tuberculosis party-wall cancer pharyngeal ulceration

Peters (E. A.), nodules of vocal cord tonsillar cancer.

Philip, osteoma of antrum dentigerous cyst

Prerce (N. H.), surgery of pituitary

Pinder (T. H.), submucous resection

Pommerenne (F.), temporo-sphenoidal abscess

Porter (W. G.), labyrinthotomy . nystagmus of cord

Powels (Fitzgerald), laryngeal neoplasm Preysing, spongification of frontal sinus Price-Brown (J.), cancer of nose, etc.

Prota (G.), pharyngeal occlusion .

Prowse (S. W.), fatal quinsy

REIK (H. O.), mastoid operation .

tobacco
REYNolds (F. E.), and FraSer (j. S.), ozæna and TURNer (A. Logan), mastoid suppuration

RichaRds (G. L.), silver nitrate in middle-ear suppuration

Richardson (C. W.), epithelioma of larynx

RichaRDSON (M. H.), cancer of tonsil

Rose (Frank), tuberculous tonsillitis

RUdLofF (W.), extra-dural abscess

RUPPRECHT, tonsils and adenoids

Rutrin (E.), labyrinthitis mucosus otitis

meningitis

otosclerosis

rotation nystagmus

temporo-sphenoidal tumour

SAFranek (J.), laryngeal lupus telangiectasis

SchaefFER (J. P.), development of nose maxillary antrum

Schamberg (J.F.), epidemic chancre of lip

Schmiegelow (E.), laryngeal cancer 


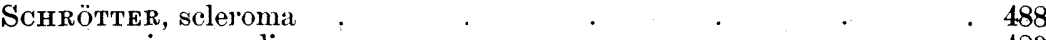

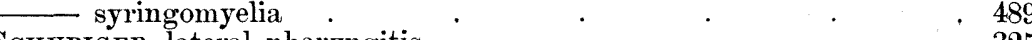

ScHUBIGER, lateral pharyngitis . $\quad . \quad \cdot \quad . \quad 325$

Scort (Sydney), fistula of labyrinth, etc. . . . . $\quad 201$

SEWELL (Lindley), deafness from mumps . $\quad . \quad$. $\quad$. 557 labyrinth fistula.

Shambaugh (G. E.), blood-vessels of nose, etc. $\quad . \quad$. $\quad .105$

\begin{tabular}{lllll} 
- tone-perception . & . &. &. & \\
\hline
\end{tabular}

Shearer (D. F.), noise machine . $\quad . \quad . \quad . \quad . \quad 553$

ShuRly (B. R.), intubation $\quad$. $\quad$. $\quad$. $\quad$. $\quad 386$

Siblex (W. Knowsley), teeth, etc. $\quad . \quad$. $\quad . \quad .437$

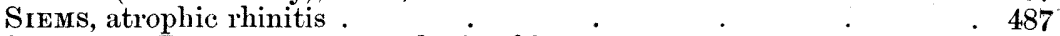

SreuR and Rouvillors, anæsthesia of larynx $\quad . \quad$. $\quad 615$

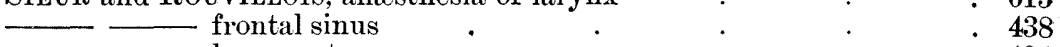

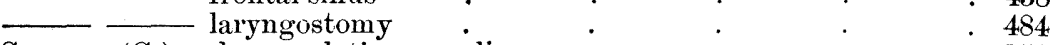

Sluder (G.), spheno-palatine ganglion $\quad . \quad 0 \quad . \quad$. $\quad . \quad 151$

SMrth (Harmon), laryngeal syphilis $\quad . \quad$. $\quad$. $\quad . \quad 321$ optic neuritis

Sмrтн (S. MacCuen), teaching of oto-laryngology

SMrTh (H. F.), lingual thyroid

Sprcer (Scanes), cancer of pharynx

rigid resistances of larynx

Stern (von), autokinesis, etc.

Stern (V. Saxtorph), wire-saw

STENGER, trauma of internal ear .

Stepinski, lactic acid

STrazzA, wounds of thyroid cartilage

Strong (L. W.), thrombo-kinase .

STUART Low (W.), cancer of nose cystic adenoma of parotid epithelioma of palate frontal sinusitis.

Syme (W. S.), anæsthesia of palate, etc. frontal sinus operation sarcoma of nose

Sxтschow (K.), laryngeal tuberculosis

TAptas, M. W. (rhinitis caseosa) .

Theisen (C. F.), lympho-sareoma of pharynx $\quad . \quad$. $\quad . \quad 317$

Theobald (S.), reflex aural neuroses $\quad . \quad$. $\quad . \quad 165$

Thompson (J. A.), bony ethmoidal eyst . . . . . $\quad$. 611

Thomson (J. J.), quinsy, fatal ․ $\quad$. $\quad$. $\quad$. $\quad$. 326

THomson (StClair), frontal sinusitis $\quad . \quad 1 \quad . \quad$. $\quad . \quad 354$ laryngeal epithelioma, stenosis $\quad . \quad 3 \quad$. $\quad . \quad 310$ nose and eye . . . . . . . $\quad . \quad 531$

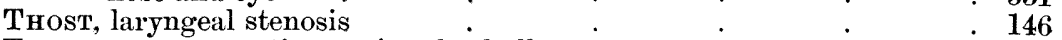

Tiefenthal, operation on jugular bulb $\quad . \quad \quad . \quad . \quad . \quad 555$

Tillex (H.), bronchiectasis from foreign body . . . . . 211

\begin{tabular}{lllll} 
bronchoscopy &. & $\cdot$ &. & \\
\hline
\end{tabular}

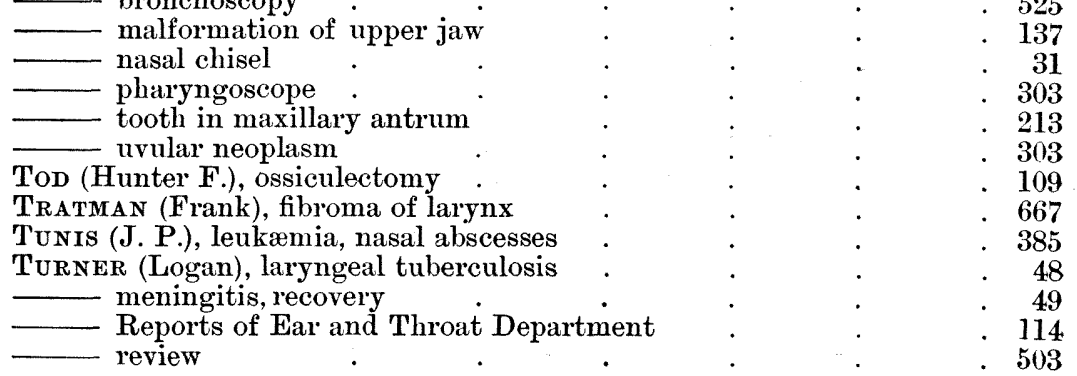

